\title{
PEMANFAATAN DATA PENGINDERAAN JAUH DAN SIG UNTUK ANALISA BANJIR (STUDI KASUS : BANJIR PROVINSI DKI JAKARTA)
}

\author{
Yuan Karisma Sang Ariyora, Yanto Budisusanto, Indah Prasasti \\ Jurusan Teknik Geomatika FTSP-ITS, Fakultas Teknik Sipil dan Perencanaan \\ Institut Teknologi Sepuluh Nopember Surabaya (ITS) \\ Jl. Arief Rahman Hakim, Surabaya 60111 Indonesia \\ Email :yanto_budisusanto@yahoo.com,septian_5990@yahoo.com
}

\begin{abstract}
Abstrak
Banjir merupakan salah satu fenomena alam yang sering terjadi di berbagai wilayah. Banjir dalam dua pengertian, yaitu : 1) meluapnya air sungai yang disebabkan oleh debit sungai yang melebihi daya tampung sungai pada keadaan curah hujan tinggi, 2) genangan pada daerah dataran rendah yang datar yang biasanya tidak tergenang. Banjir merupakan salah satu bencana yang sering terjadi di Indonesia, khususnya kota-kota besar seperti Jakarta.Daerah bahaya banjir dapat diidentifikasi secara cepat dengan menggunakan memanfaatkan data Penginderaan Jauh yaitu tumpang susun/overlay terhadap parameterparameter banjir, seperti : curah hujan, bentuk penggunaan lahan (landuse), tekstur tanah, dan kemiringan lereng. Serta perpaduan visualisasi persebaran banjir dengan SIG (Sistem Informasi Geografi). Pembagian kelas dari setiap parameter yang digunakan secara umum disesuaikan dengan kelas parameter yang dimiliki oleh daerah yang diamati.Nilai bobot dan skor juga menyesuaikan dengan daerah penelitian yang diamati. Dalam penelitian ini, nilai bobot dan skor yang digunakan merupakan modifikasi dari nilai bobot dan skor. Dari hasil bobot dan skoring lalu menghitung Nilai potensi suatu daerah terhadap genangan ditentukan dari total penjumlahan skor masing-masing parameter genangan. Daerah yang sangat berpotensi terhadap genangan akan memiliki skor total dengan jumlah paling besar dan sebaliknya daerah yang tidak berpotensi terhadap genangan akan mempunyai total skor yang rendah. Tabel berikut menunjukkan tingkat potensi genangan berdasarkan nilai penjumlahan skor masing-masing parameter genangan. Hasil yang didapatkan penetapan kawasan bahaya banjir, ternyata daerah bahaya banjir yang dibuat Pemerintah Provinsi DKI 100\% semuanya masuk dalam daerah sangat bahaya banjir berdasarkan hasil penelitian.Hal ini terjadi karena memang setiap musim penghujan daerah-daerah bahaya tersebut selalu mengalami banjir atau langganan banjir.
\end{abstract}

Kata Kunci : Curah Hujan,Tekstur Tanah, Kemiringan Lereng, Penggunaan Lahan, Skor, Bobot, Banjir, dan Jakarta

\section{PENDAHULUAN}

\section{Latar Belakang}

Menurut Richard (1995) pada Suherlan (2001) mengartikan banjir dalam dua pengertian, yaitu : 1) meluapnya air sungai yang disebabkan oleh debit sungai yang melebihi daya tampung sungai pada keadaan curah hujan tinggi, 2) genangan pada daerah dataran rendah yang datar yang biasanya tidak tergenang. Adapun faktor penyebab banjir menurut Sutopo (1999) pada Ramdan (2004) banjir dibedakan menjadi persoalan yang disebabkan aktifitas penduduk dan kondisi alam. Faktor aktifitas penduduk berpengaruh terhadap keadaan banjir seperti tumbuhnya daerah budidaya di daerah dataran banjir, penimbunan daerah rawa atau situ, menyempitnya alur sungai akibat adanya pemukiman di sepanjang sepadan sungai. Sedangkan pengaruh dari kondisi alam yang dimaksud antara lain curah hujan yang tinggi, melimpasnya air sungai, dan bendungan muara sungai akibat air pasang dari laut.

Banjir merupakan salah satu bencana yang sering terjadi di Indonesia, khususnya kota-kota besar seperti Jakarta. Banjir yang terjadi di Jakarta membentuk suatu peristiwa periodisasi atau kala ulang. Periodisasi banjir bisa terjadi dalam kala ulang 100 tahun, 50 tahun, 20 tahun, 10 tahun, dan sekarang telah menjadi siklus atau kala ulang lima tahunan. Meskipun sebenarnya setiap tahun Kota Jakarta mengalami banjir, hanya saja ada tahun-tahun yang kejadian banjirnya sangat 
besar, ada pula tahun-tahun yang banjirnya berkurang. Menurut sejarahnya Jakarta sudah dilanda banjir ketika masih disebut Batavia, yaitu sejak tahun 1621, 1654, 1873, dan 1918 pada masa pemerintahan kolonial Belanda. Pada dekade terakhir ini, banjir besar terjadi pada tahun 1979, 1996, 1999, 2002, 2007 (Kusumaputra, 2010).

Dari tahun ke tahun kejadian banjir di Jakarta seperti sebuah aktifitas rutin. Pada tahun 2012 tercatat kerugian Provinsi DKI Jakarta. Dapat dijelaskan dalam table berikut ini:

Tabel 1 Bencana Banjir Provinsi DKI Jakarta

\begin{tabular}{|c|c|c|c|c|}
\hline \multicolumn{5}{|c|}{$\begin{array}{c}\text { BENCANA BANJIR, KORBAN DAN PROVINSI } \\
\text { DKI JAKARTA TAHUN } 2012\end{array}$} \\
\hline \multirow{2}{*}{ NO } & \multirow{2}{*}{\multicolumn{2}{|c|}{$\begin{array}{cc} & \text { TOTAL } \\
& \text { AREA } \\
\text { KOTA } & \text { TEREN } \\
& \text { DAM } \\
& \text { (Ha) }\end{array}$}} & \multicolumn{2}{|c|}{ KORBAN } \\
\hline & & & MENGUNGSI & MENINGGAL \\
\hline 1 & $\begin{array}{l}\text { JAKARTA } \\
\text { SELATAN }\end{array}$ & 1 & 8.911 & 1 \\
\hline 2 & $\begin{array}{l}\text { JAKARTA } \\
\text { TIMUR }\end{array}$ & 1 & 3.700 & 0 \\
\hline 3 & $\begin{array}{l}\text { JAKARTA } \\
\text { PUSAT }\end{array}$ & 1 & 500 & 0 \\
\hline 4 & $\begin{array}{l}\text { JAKARTA } \\
\text { BARAT }\end{array}$ & 1 & 12.500 & 2 \\
\hline 5 & $\begin{array}{l}\text { JAKARTA } \\
\text { UTARA }\end{array}$ & 1 & 800 & 1 \\
\hline & TOTAL & 5 & 26.491 & 4 \\
\hline
\end{tabular}

Sumber : Dinas Pemadam Kebakaran dan

Perkembangan teknologi yang semakin cepat memberikan solusi tersendiri dalam pemecahan masalah banjir. Daerah bahaya banjir dapat diidentifikasi secara cepat dengan melakukan analisa tumpang susun/overlay terhadap parameter-parameter banjir, seperti : curah hujan, bentuk muka bumi (landform), tekstur tanah, kemiringan lereng, tutupan lahan dan buffer sungai

\section{Perumusan Masalah}

Dari latar belakang di atas perumusan masalah di dapat yaitu :

1. Bagaimana mengelolah parameter penyebab banjir dengan menggunakan perangkat lunak SIG?

2. Bagaimana membuat peta bahaya banjir untuk kawasan DKI Jakarta dengan Metode 138
Skoring,pembobotan dan overlay dengan tampilan SIG (Sistem Informasi Geografi)?

\section{METODOLOGI PENELITIAN}

Lokasi Penelitian

Lokasi penelitian ini mengambil studi kasus Propinsi DKI Jakarta terletak pada 106 derajat 49' 35" Bujur Timur dan 06 derajat 10' 37" Lintang Selatan. Luas Wilayah 650,40 Km2 termasuk Kepulauan Seribu, 9.20 (Km2). Berada di dataran rendah pantai Utara Bagian Barat Pulau Jawa.Terdapat sekitar 10 buah sungai alam dan buatan.

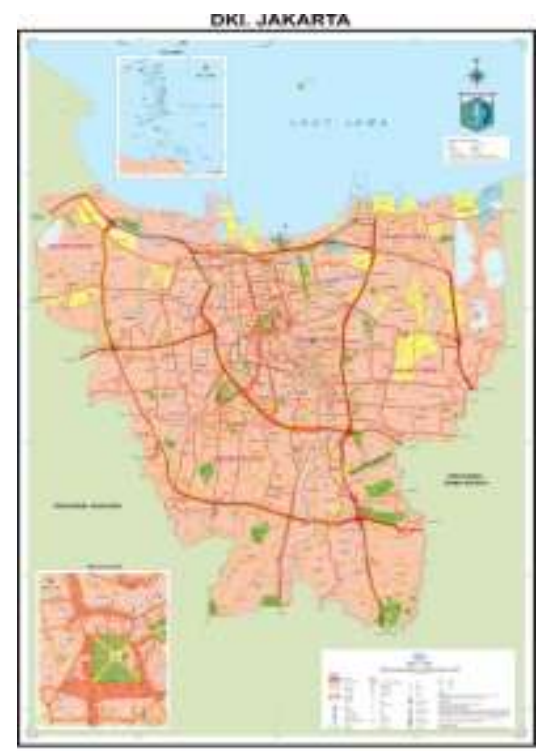

Gambar 1. Lokasi Penelitian (Bakosurtanal 2003)

\section{Data Dan Peralatan}

\section{- Data}

Data yang dibutuhkan dalam penelitian Tugas Akhir ini antara lain :

1. Citra Landsat ETM+ wilayah Jabodetabek tahun 2012 yang telah terkoreksi dari LAPAN

2. Data curah hujan harian tahun 2012 dari stasiun pengamatan curah hujan di Jabodetabek dari BMKG dan Dinas PU Pengairan DAS Ciliwung -Cisadane

3. Data DEM SRTM dari USGS tahun 2000

4. Data Tekstur Tanah dari LAPAN

5. Data DAS (Daerah Aliran Sungai) di Jabodetabek tahun 2012

6. Peta vektor Rupa Bumi Indonesia (RBI) skala 1: 25.000 
7. Data Titik Bahaya Banjir tahun 2012 dari BNPB.

\section{- Peralatan}

Peralatan yang digunakan dalam penelitian ini adalah :

1. Perangkat Keras (Hardware)

1 unit Laptop merk HP Compaq 420

2. Perangkat Lunak (Software)

a. Sistem operasi berbasiskan Windows 7

b. Sistem aplikasi berupa Microsoft Tools 2007 Microsoft Word, Microsoft Excel dan Microsoft Power Point)

c. Sistem aplikasi berupa Microsoft Visio 2007

d. Sistem aplikasi berupa software ArcGIS 10.2

e. Sistem aplikasi berupa software $\mathrm{Er}$ Mapper 7.0

\section{Tahapan Penelitian}

Tahapan yang dilaksanakan dalam penelitian ini adalah :

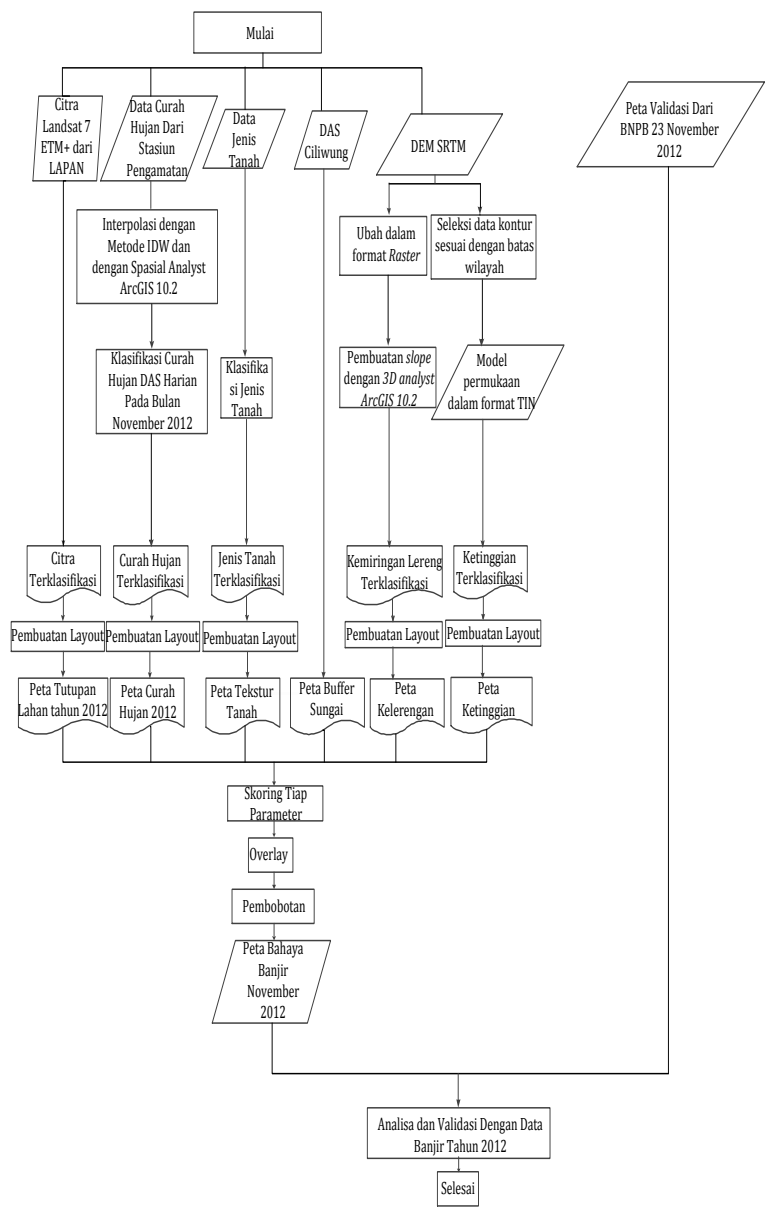

Gambar 2. Diagram Alir Penelitian
1. Mulai

2. Citra Landsat ETM +7

Citra telah terkoreksi dan terklasifiksi menjadi 12 Kelas penggunaan lahan. Diantaranya pemukiman, badan air, Industri, hutan, belukar, perkebunan, sawah, lahan terbuka, tegalan, rumput, tambang dan Kebun campuran. Kemudian dilakukan reclassify sesuai skoring yang dijadikan acuan menjadi 6 kelas.

3. Pengolahan Data Curah Hujan Stasiun

Pengolahan data curah hujan dari stasiun pengamatan menjadi peta curah hujan. Data didapatkan berupa nilai curah hujan dalam satuan $(\mathrm{mm})$ dengan format xls. Data yang digunakan adalah jumlah curah hujan harian pada sebelum terjadi banjir, ketika terjadi banjir dan setelah terjadi banjir dalam kurun waktu \pm 8 hari tiap bulan kejadian banjir. Kemudian data tersebut dibuka dengan menggunan ArcGIS 10.2, di export dalam format (shapefile), ubah projeksi halaman dalam UTM (Universal Transverse Mercator) zona Selatan 49, setelah itu dilakukan proses Interpolasi pada Spasial Analyst Tools dengan IDW (Interpolation Distance Weight) sesuai dengan batas wilayah yang diteliti, dari hasil interpolasi kemudian dilakukan reclassify sesuai skoring yang dijadikan acuan menjadi 9 kelas.

4. Data Jenis Tanah

Data Jenis tanah didapatkan dari data geologi yang diolah dari satelit Radarsat kemudian diolah menjadi peta tekstur tanah data ini sudah dalam format raster yang telah dilakukan reclassify menjadi Peta Tekstur tanah. Tekstur tanah yang didapatkan dari LAPAN memiliki 4 kelas.

5. DAS di Wilayah Jabodetabek, data ini didapatkan dari LAPAN. Sub das dari DAS di wilayah jabodetabek di buffer menjadi 3 radius antara lain $25 \mathrm{~m}, 200 \mathrm{~m}$ dan $250 \mathrm{~m}$. Setelah itu dilakukan penggabungan dengan Merge pada Analyst Tools untuk menggabungkan ketiga radius, kemudian dilakukan Dissolve untuk membuat atribut menjadi lebih sederhana, hal ini dilakukan untuk menentukan kelas buffer sungai menjadi 3 kelas. 
6. Citra SRTM

7. Citra SRTM dalam format raster diolah menjadi kontur dengan aplikasi create contour pada raster surface di 3D Analyst Tools. Kemudian hasilnya diubah dalam 2 parameter kelerengan dan ketinggian. Untuk membuat kelerengan (slope) dengan create slope dari data contour, kemudian dilakukan reclassify menjadi 5 kelas sesuai acuan parameter. Sedangkan untuk ketinggian dilakukan lagi proses TIN (Triangulated Irregular Network) untk mendapatkan elevasi yang diinginkan, kemudian dilakukan reclassify menjadi 6 Kelas. yang akan diklasifikasi dan dihasilkan peta kelerengan yang dilakukan dengan software ArcGIS 10.2

8. Skoring dan Pembobotan

Skoring dan Pembobotan adalah proses pengolahan data yang dilakukan setelah proses reclassify. Proses ini dilakukan dengan cara memberikan nilai pada setiap parameter penyebab banjir, kemudian dilakukan perhitungan dengan mempertimbangkan faktor terbesar yang menyebabkan terjadinya banjir. Pembuatan Peta kejadian banjir DKI Jakarta tahun 2012 dengan software ArcGIS 10.2. Pembuatan Peta bahaya banjir DKI Jakarta tahun 2012 dengan software ArcGIS 10.2 .

9. Overlay

Overlay adalah proses penggabungan 6 parameter banjir dari peta penggunaan lahan, peta curah hujan, peta tekstur tanah, peta buffer sungai, peta kelerengan dan peta ketinggian yang telah dilakukan skoring dengan menggunakan Union pada Spasial Analyst Tools dan dihasilkan Peta Bahaya Banjir rentang tahun 2012.

10. Overlay Peta Bahaya Banjir dan Peta Persebaran Banjir dengan peta administrasi.

Hasil dari Overlay kemudian di Analisa dan dilakukan uji ketelitian dengan titik bahaya banjir di DKI Jakarta tahun 2012 dari BNPB

11.Selesai

\section{HASIL DAN ANALISA}

\section{Peta Penggunaan Lahan Jabodetabek}

Data Penggunaan lahan diperoleh dari LAPAN Pusfatja. Citra yang digunakan untuk penggunaan lahan adalah Citra Satelit

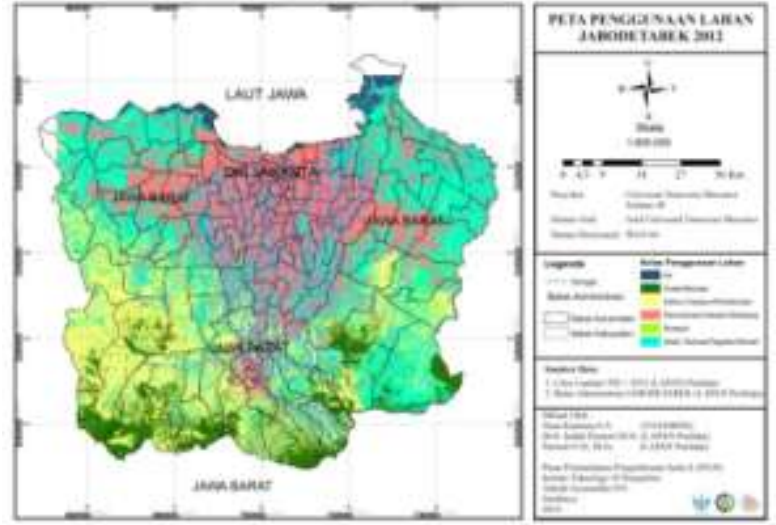

Gambar 3. Hasil Pengolahan Citra Landsat ETM + 7 tahun 2012 menjadi Peta Penggunaan Lahan Jabodetabek

Sumber : LAPAN PUSFATJA

Landsat ETM + 7(Enhanced Thematic Mapper 7) tahun 2012 untuk daerah Jabodetabek yang telah dilakukan koreksi geometrik dan koreksi radiometrik. Interpretasi visual dilakukan dengan metode Supervise Classification, kemudian dilakukan grapfill dan mozaiking. Selanjutnya dilakukan perhitungan cofussion matrix.

Dalam penelitian yang telah dilakukan oleh peneliti di LAPAN Pusfatja didapatkan 12 Kelas penggunaan lahan antara lain :

Tabel 2 Luas Area Penggunaan Lahan Jabodetabek

\begin{tabular}{|c|c|c|c|}
\hline \multicolumn{4}{|c|}{ Luas Penggunaan Lahan Wilayah Jabodetabek } \\
\hline No & Kelas & Luas(ha) & Luas(\%) \\
\hline 1 & Badan Air & 16144,67 & 2,41 \\
\hline 2 & $\begin{array}{c}\text { Sawah,Tegalan,Lahan } \\
\text { Terbuka }\end{array}$ & $\begin{array}{c}232254,2 \\
3\end{array}$ & 34,74 \\
\hline 3 & Pemukiman & $\begin{array}{c}197378,6 \\
0\end{array}$ & 29,52 \\
\hline 4 & Padang Rumput & 4863,82 & 0,73 \\
\hline 5 & $\begin{array}{c}\text { Kebun Campuran dan } \\
\text { Perkebunan }\end{array}$ & $\begin{array}{c}158050,4 \\
7\end{array}$ & 23,64 \\
\hline 6 & Hutan dan Semak Belukar & 59834,58 & 8,9 \\
\hline & Jumlah & $\mathbf{6 6 8 5 2 6 , 4}$ & $\mathbf{1 0 0}$ \\
\hline
\end{tabular}

Sumber :LAPAN Pusfatja 2012 


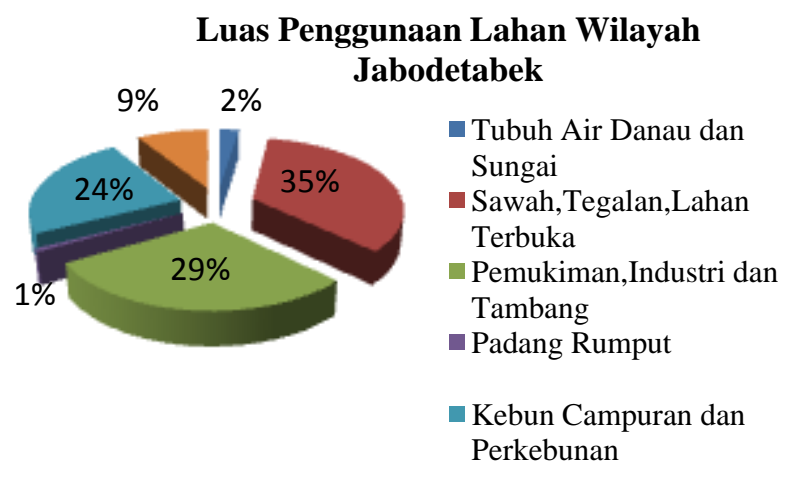

Gambar 4. Diagram Alir Luas Wilayah Penggunaan Lahan Wilayah Jabodetabek Sumber : Hasil Perhitungan

Dari hasil Tabel 2 dan Gambar 3 pemetaan distribusi daerah bahaya banjir di semua wilayah Jabodetabek pada tahun 2012 menunjukkan bahwa tingkat penggunaan lahan untuk lahan terbuka, tegalan dan sawah memiliki luasan yang paling besar diantara kelas penggunaan lahan yang lainnya dengan presentase mencapai 34,74 $\%$. Kelas penggunaan lahan untuk lahan terbuka, tegalan dan sawah diberi skor 8 hal ini menunjukkan bahwa wilayah jakarta memiliki potensi bahaya banjir dengan kriteria sangat bahaya. Selain itu tingkat luas daerah pemukiman, industri Tambang menduduki peringkat kedua dengan presentase sebesar 29,52\%. Kelas penggunaan lahan ini diberi skor 6 hai ini menunjukkan bahwa wilayah jakarta memiliki potensi bahaya banjir dengan kriteria sangat bahaya.

Sedangkan luasan area kebun Campuran dan hutan berbanding terbalik dengan presentase antara 0,73-8,9 \%. Pada dasarnya area Kebun Campuran dan hutan adalah daerah yang sangat berperan besar sebagai daerah resapan air hujan. Dari pembuktian dua kelas luas penggunaan lahan yang terbesar menunjukkan bahwa Jakarta memiliki daerah bahaya banjir bahaya banjir yang sangat tinggi.

\section{Hasil Perhitungan Curah Hujan 2012Wilayah Jabodetabek}

Hasil interpolasi curah hujan dari rentang tahun 2012 yang dijadikan penelitian didapatkan Curah
Hujan pada Kejadian Bahaya Banjir adalah sebagai berikut:

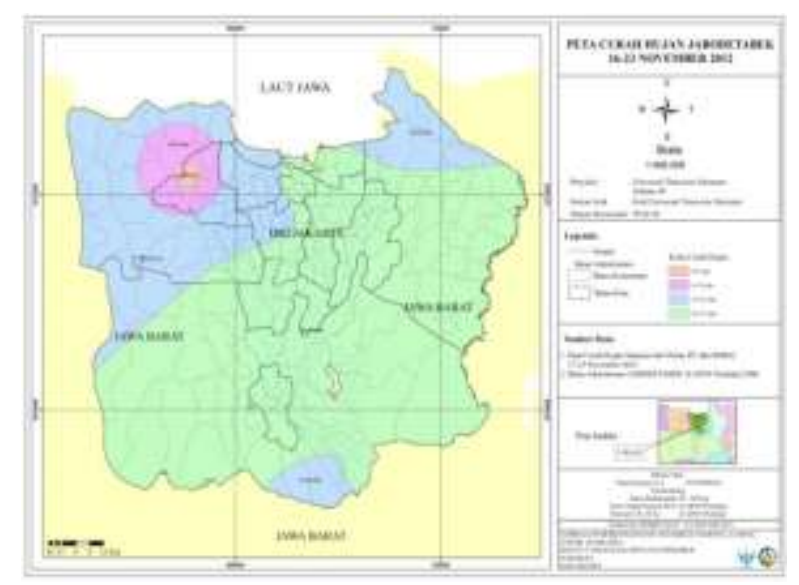

Gambar 5 Peta Interpolasi Curah Hujan Stasiun dengan menggunakan IDW (Interpolation Distance Weight) Tanggal 16 -23 November 2012 Sumber : Hasil Penelitian

Dari gambar 4. Didapatkan hasil perhitungan lus wilayah jangkauan curah hujan sebagai berikut :

Tabel 3 Luas Curah Hujan 16-23 November 2012 Jabodetabek

Luas Curah Hujan Jabodetabek Tanggal 16-23 November 2012

\begin{tabular}{ccccc}
\hline No & Kelas & Keterangan & Luas (ha) & Luas(\%) \\
\hline 1 & $0-5 \mathrm{~mm}$ & $\begin{array}{c}\text { Hujan } \\
\text { Ringan }\end{array}$ & 2197.34 & 0.47 \\
2 & $6-12 \mathrm{~mm}$ & $\begin{array}{c}\text { Hujan } \\
\text { Ringan } \\
\text { Hujan }\end{array}$ & 26302.23 & 5.66 \\
3 & $13-25 \mathrm{~mm}$ & $\begin{array}{c}\text { Sedang } \\
\text { Hujan }\end{array}$ & 0 & 0 \\
4 & $26-37 \mathrm{~mm}$ & $\begin{array}{c}\text { Sedang } \\
\text { Total }\end{array}$ & 435510.57 & 93.85 \\
\hline
\end{tabular}

Sumber : Hasil Penelitian

Dari Gambar 5 dan Tabel 3 Menunjukkan hasil Curah hujan tahun 2012 di wilayah Jabodetabek yang memiliki prosesntase kelas 4 terbesar dengan luas $93.858 \%$.

\section{Peta Tekstur Tanah Jabodetabek}

Analisis peta Jenis Tanah dilakukan untuk mempersiapkan peta tekstur tanah dan peta drainase tanah. Untuk membuat peta tekstur tanah dan drainase tanah menggunakan metode digitasi on screen setelah terlebih dahulu melakukan koreksi geometrik terhadap Peta Jenis Tanah. Hal ini sudah dilakukan oleh LAPAN. Dan hasil dari Peta Tekstur Tanah adalah sebagai berikut: 


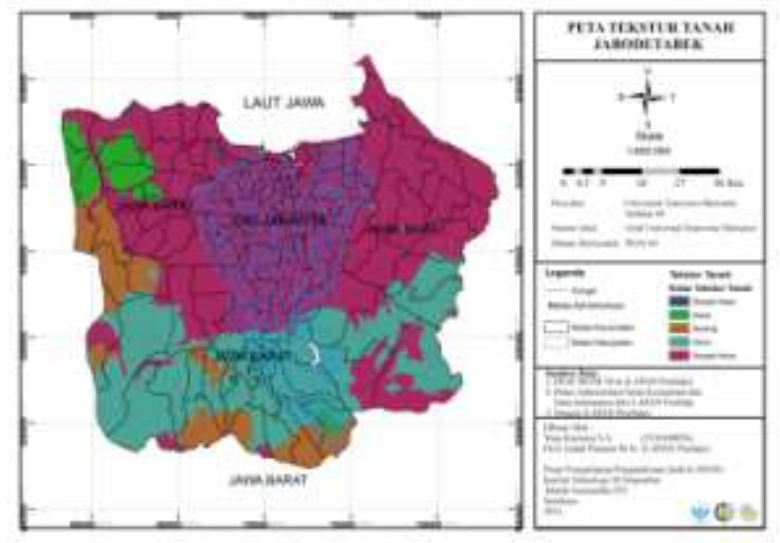

Gambar 6 Peta Tekstur Tanah Wilayah Jabodetabek Sumber : LAPAN

Dari Gambar 6 Wilayah Jabodetabek memiliki 5 kelas Tekstur tanah. Diantaranya Tekstur tanah Sangat Halus, Halus, Sedang, Kasar dan Sangat Kasar. Untuk mengetahui Luas tekstur tanah disajikan dalam tabel 4 Berikut ini :

Tabel 4 Luas Tekstur Tanah Wilayah Jabodetabek

\begin{tabular}{cccc}
\hline \multicolumn{4}{c}{ Luas Tekstur TanahWilayah Jabodetabek } \\
\hline No & Kelas & Luas (ha) & Luas (\%) \\
\hline 1. & Sangat Kasar & 1682,911 & 0,27318 \\
2. & Kasar & 26874,07 & 4,362359 \\
3. & Sedang & 26874,07 & 4,362359 \\
4. & Halus & 186528,1 & 30,27836 \\
5. & Sangat Halus & 374085,3 & 60,72375 \\
& Jumlah & $\mathbf{6 1 6 0 4 4 , 5}$ & $\mathbf{1 0 0}$ \\
\hline
\end{tabular}

Sumber : Hasil Penelitian

\section{Luas Tekstur Tanah Wilayah} Jabodetabek

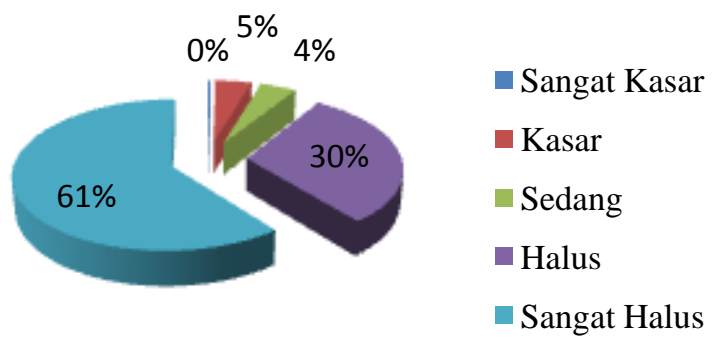

Gambar 7. Diagram Luas Tekstur Tanah Wilayah Jabodetabek

Sumber : Hasil Perhitungan
Dari hasil Klasifikasi Peta Jenis tanah menjadi Peta Tekstur Tanah, yang memiliki presentase paling besar adalah pada kelas Sangat Halus. Dari hasil penelitian Luas wilayah pada tabel 4 untuk kelas Tekstur Tanah Sangat Halus adalah 61\%. Sedangkan $40 \%$ dari sisa kelasnya terdapat 4 kelas diantaranya kelas halus, sedang, kasar dan sangat kasar. Hal ini menunjukkan bahwa wilayah DKI Jakarta memiliki jenis tanah dengan penyerapan air yang buruk sehingga air hujan tidak dapat diserap dengan baik oleh tanah dan berpotensi besar terhadap bahaya banjir.

\section{Peta Kemiringan Lereng Jabodetabek}

Kemiringan lereng di Wilayah Jabodetabek sangat bervariasi. Wilayah yang memiliki Kemiringan lereng sangat rendah dengan kelas datar berada di hampir seluruh provinsi DKI Jakarta, Bekasi Jawa barat dan Tanggerang Banten. Sedangkan dikisaran kemiringan dengan kelas berombak berada di Wilayah Depok, sedangkan kelas bergelombang hingga terjal berada di bagian selatan yakni Wilayah Bogor Jawa Barat.

Hal ini menunjukkan bahwa jakarta sangat rentan terjadi banjir, karena aliran air dari bogor langsung menuju ke jakarta. Dengan prinsip bahwa air mengalir menuju ke wilayah yang lebih rendah.Berikut adalah gambar yang menunjukkan hasil klasifikasi Kemiringan lereng :

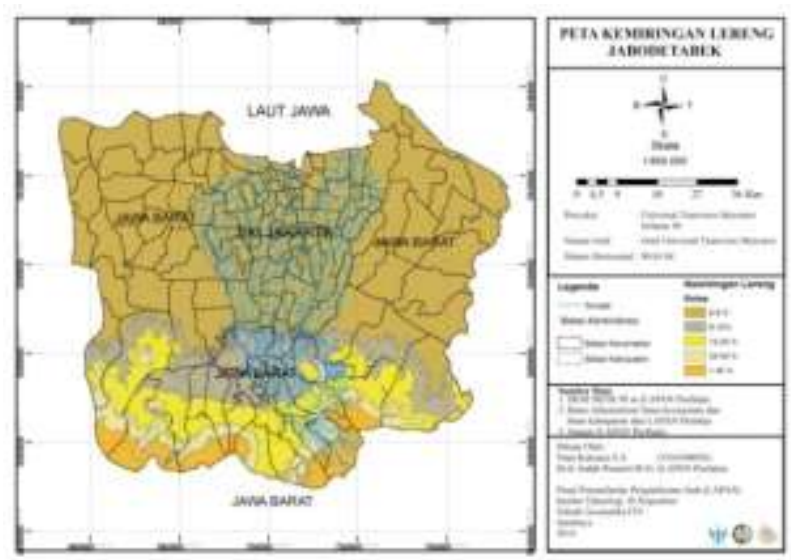

Gambar 8. Peta Kemiringan Lereng dengan Pembagian 5 Kelas Sumber : Hasil Penelitian

Dari Gambar 8 Wilayah Jabodetabek memiliki 5kelas Kemiringan Lereng. Diantaranya adalah kemiringan lereng dengan persentase 0-8 \% dengan kelas Datar, $8-12 \%$ dengan kelas 
Berombak, 12-25\% dengan kelas Bergelombang, 25-40 \% dengan kelas Berbukit, dan $>40 \%$ dengan kelas Curam/Terjal.

Tabel 5. Luas Kemiringan Lereng Wilayah Jabodetabek

\begin{tabular}{|c|c|c|c|c|}
\hline \multicolumn{5}{|c|}{ Luas Kemiringan Lereng Jabodetabek } \\
\hline No & Kelas & Keterangan & Luas (ha) & Luas (\%) \\
\hline 1 & $0-8 \%$ & Datar & 634740,57 & 22,75 \\
\hline 2 & $8-15 \%$ & Berombak & 621061,74 & 22,26 \\
\hline 3 & $15-25 \%$ & Bergelombang & 606587,67 & 21,74 \\
\hline 4 & $25-40 \%$ & Berbukit & 501885,54 & 17,99 \\
\hline 5 & $>40 \%$ & Curam/Terjal & 425931,12 & 15,27 \\
\hline \multicolumn{3}{|c|}{ Jumlah } & 2790206,64 & 100 \\
\hline
\end{tabular}

Sumber : Hasil Penelitian

Pada Tabel 5 Menunjukkan Luas Kemiringan lereng di wilayah Jabodetabek. dan ditunjukkan dalam diagram berikut ini:

\section{Luas Kemiringan Lereng} Jabodetabek (ha)

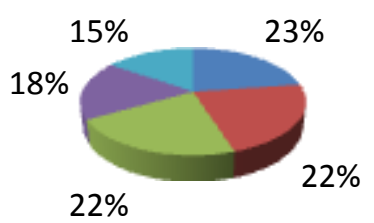

$$
\begin{aligned}
& \text { Datar } \\
& \text { Berombak } \\
& \text { Bergelombang }
\end{aligned}
$$

Gambar 9. Diagram Luas kemiringan Lereng Wilayah Jabodetabek

Sumber : Hasil Perhitungan

Dari hasil klasifikasi Kemiringan lereng didapatkan Kelas dengan rentang 0-8 \% memiliki luas yang terbesar mencapai $22,75 \%$. Hal ini merupakan pemicu terhadap terjadinya bahaya banjir di wilayah yang lebih rendah.

\section{Peta Ketinggian Jabodetabek}

Kelas ketinggian digunakan dalam penentuan kelas kebahaya banjiran karena ketinggian berpengaruh dalam proses terjadinya banjir. Dimana dilihat dari sifat air yang selalu mengalir dari daerah yang tinggi ke daerah yang lebih rendah sehingga daerah dengan ketinggian yang lebih rendah mempunyai potensi lebih tinggi untuk terjadinya banjir.

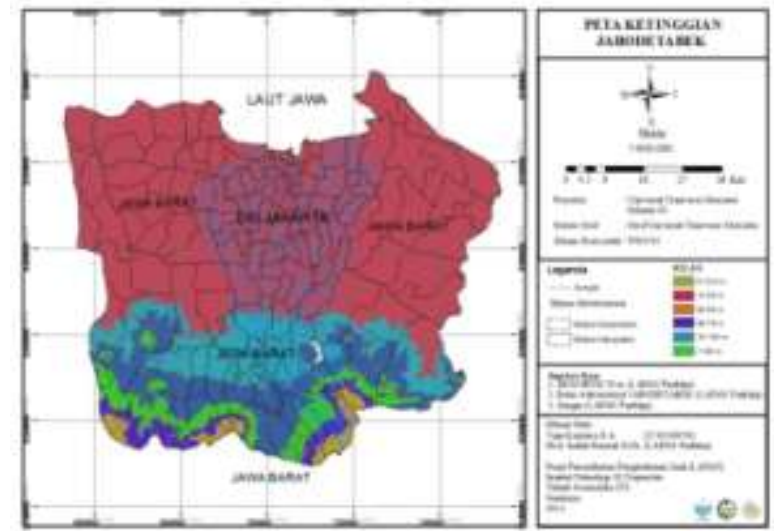

Gambar 10. Peta Ketinggian dengan Pembagian 6 Kelas

Sumber : Hasil Penelitian

Pada peta diatas menunjukan bahwa di wilayah jabodetabek terdapat 6 kelas ketinggian mulai dari ketinggian $0 \mathrm{mdpl}->100 \mathrm{mdpl}$.Adapun setiap kelas memiliki perbedaan luasan yang akan dijelaskan dalam tabel di bawah ini:

Tabel 6. Luas Ketinggian Wilayah Jabodetabek

\begin{tabular}{cccc}
\hline \multicolumn{4}{c}{ Luas Ketinggian Wilayah Jabodetabek } \\
\hline No & Kelas & Luas (ha) & Luas (\%) \\
\hline 1 & $0-12,5 \mathrm{~m}$ & 631106.26 & 18.4949 \\
2 & $12,5-25 \mathrm{~m}$ & 626373.43 & 18.3562 \\
3 & $25-50 \mathrm{~m}$ & 620527.25 & 18.18487 \\
4 & $50-75 \mathrm{~m}$ & 606360.66 & 17.76971 \\
5 & $75-100 \mathrm{~m}$ & 502554.23 & 14.72761 \\
6 & $>100 \mathrm{~m}$ & 425404.92 & 12.46671 \\
& Jumlah & 3412326.75 & 100 \\
\hline
\end{tabular}

Sumber : Hasil Penelitian

Luas Wilayah Jabodetabek (ha)

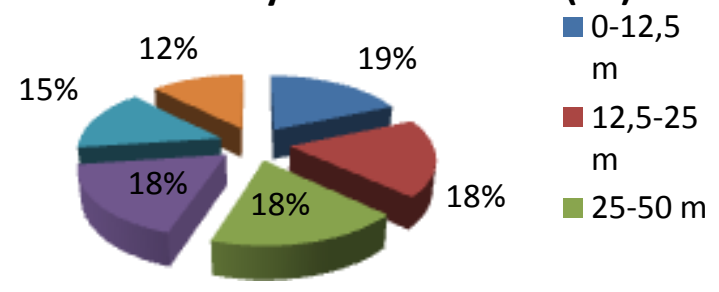

Gambar 11. Diagram Luas Ketinggian Wilayah Jabodetabek Sumber : Hasil Perhitungan

\section{Peta Buffer Sungai Jabodetabek}

Buffer sungai adalah suatu daerah yang mempunyai lebar tertentu yang digambarkan di sekeliling sungaidengan jarak tertentu. Buffer 
sungai dibuat berdasarkan logika dan pengetahuan mengenai hubungan sungai dan kejadian banjir. Dengan asumsi semakin dekat dengan sungai, maka peluang untuk terjadinya banjir lebih tinggi. Peta buffer sungai dibuat berdasarkan zona buffer sungai yang dihasilkan dari pengkelasan tingkat kebahaya banjiran banjir suatu wilayah jabodetabek berdasarkan jarak dengan sungai.

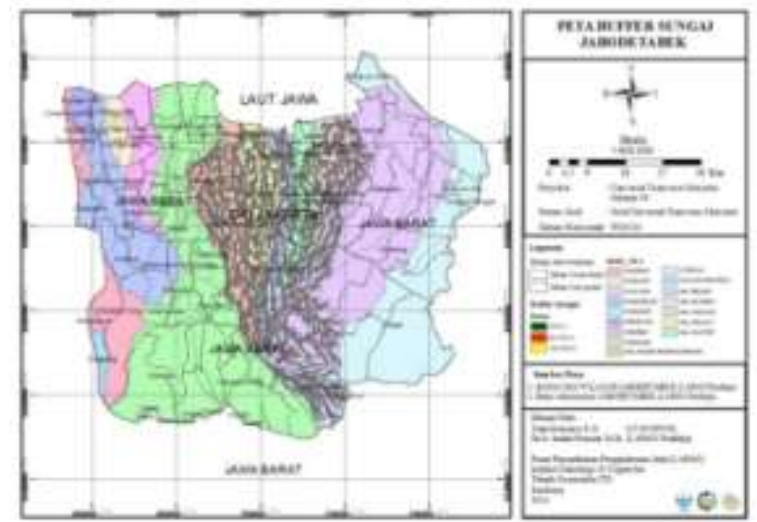

Gambar 12. Peta Buffer Sungai dengan Pembagian 3 Kelas Wilayah Jabodetabek

Sumber : Hasil Penelitian

Pada peta diatas dijelaskan bahwa kelas buffer sungai mempunyai kelas 1 dengan radius $0-25 \mathrm{~m}$, kelas 2 dengan radius $25-100 \mathrm{~m}$ dan kelas 3 dengan radius $100-250 \mathrm{~m}$. Hasil penelitian yang telah dilakukan Di Wilayah Jabodetabek. Sungai yang mengalir di wilayah Jabodetabek yang berakibat terhadap banjir di Wilayah DKI Jakarta. Batas Daerah Aliran Sungai yang menjadi penyebab langganan banjir adalah Sungai Ciliwung, Kali Angke, Kali Buaran, Sungai Cirarab dan Sungai Cisadane.

\section{Overlay dan Pembobotan}

Dalam menentukan tingkat potensi daerah bahaya, dilakukan overlay atau pertampalan dari berbagai variabel penentu daerah bahaya banjir dengan metode skoring, yaitu pemberian bobot dan skor. Dari hasil pertampalan, daerah yang memiliki total skor terbanyak merupakan daerah yang berpotensi bahaya banjir.

Penentuan bobot dan skor beracuan pada contoh tabel skoring yang terdapat pada tinjauan pustaka namun dengan modifikasi untuk penyesuaian dengan area Jabodetabek dan DKI jakarta.
Berikut ini adalah tabel yang memuat bobot dari setiap variabel penentu daerah bahaya banjir, serta skor subvariabel dari masing-masing variabel.

Tabel 7. Skoring Variabel Penentu Daerah Potensi Bahaya Banjir

\begin{tabular}{|c|c|c|c|c|c|c|}
\hline No & Variabel & Kelas & Keterangan & Skor & $\begin{array}{c}\text { Bobot } \\
(\%)\end{array}$ & Total \\
\hline 1 & \multirow{6}{*}{$\begin{array}{l}\text { Curah } \\
\text { Hujan }\end{array}$} & $\begin{array}{l}(0-5) \\
\mathrm{mm}\end{array}$ & $\begin{array}{l}\text { Hujan } \\
\text { Ringan }\end{array}$ & 1 & \multirow{6}{*}{20} & 0.2 \\
\hline 2 & & $\begin{array}{l}(6-12) \\
\mathrm{mm}\end{array}$ & & 3 & & 0.6 \\
\hline 3 & & $\begin{array}{c}(13-25) \\
\mathrm{mm}\end{array}$ & & 5 & & 1 \\
\hline 4 & & $\begin{array}{c}(26-37) \\
\mathrm{mm}\end{array}$ & $\begin{array}{l}\text { Hujan } \\
\text { Sedang }\end{array}$ & 7 & & 1.4 \\
\hline 5 & & $\begin{array}{c}(38-50) \\
\mathrm{mm}\end{array}$ & & 9 & & 1.8 \\
\hline 6 & & $\begin{array}{c}(51-75) \\
\mathrm{mm}\end{array}$ & & 9 & & 1.8 \\
\hline 1 & \multirow{7}{*}{$\begin{array}{c}\text { Tutupan } \\
\text { Lahan }\end{array}$} & & Badan Air & 9 & \multirow{7}{*}{20} & 1.80 \\
\hline 2 & & & Tambak & 9 & & 1.80 \\
\hline 3 & & & Sawah & 8 & & 1.60 \\
\hline 4 & & & Pemukiman & 6 & & 1.20 \\
\hline 5 & & & $\begin{array}{l}\text { Padang } \\
\text { Rumput }\end{array}$ & 5 & & 1.00 \\
\hline 6 & & & $\begin{array}{c}\text { Kebun } \\
\text { Campuran }\end{array}$ & 3 & & 0.60 \\
\hline 7 & & & Hutan & 1 & & 0.20 \\
\hline 1 & \multirow{5}{*}{$\begin{array}{l}\text { Kemirin } \\
\text { gan } \\
\text { Lereng }\end{array}$} & $0-8 \%$ & Datar & 9 & \multirow{5}{*}{20} & 1.8 \\
\hline 2 & & $8-15 \%$ & Berombak & 7 & & 1.4 \\
\hline 3 & & $15-25 \%$ & $\begin{array}{l}\text { Bergelomba } \\
\text { ng }\end{array}$ & 5 & & 1 \\
\hline 4 & & $25-40 \%$ & Berbukit & 3 & & 0.6 \\
\hline 5 & & $>40 \%$ & Curam & 1 & & 0.2 \\
\hline 1 & \multirow{5}{*}{$\begin{array}{l}\text { Tekstur } \\
\text { Tanah }\end{array}$} & 1 & $\begin{array}{l}\text { Sangat } \\
\text { Halus }\end{array}$ & 9 & \multirow{5}{*}{10} & 0.9 \\
\hline 2 & & 2 & Halus & 7 & & 0.7 \\
\hline 3 & & 2,5 & Sedang & 5 & & 0.5 \\
\hline 4 & & 3 & Kasar & 3 & & 0.3 \\
\hline 5 & & 4 & $\begin{array}{l}\text { Sangat } \\
\text { Kasar }\end{array}$ & 1 & & 0.1 \\
\hline 1 & \multirow{6}{*}{$\begin{array}{c}\text { Ketinggi } \\
\text { an }\end{array}$} & $\begin{array}{c}0 \mathrm{~m}- \\
12,5 \mathrm{~m}\end{array}$ & & 9 & \multirow{6}{*}{10} & 0.9 \\
\hline 2 & & $\begin{array}{c}12,6 \mathrm{~m}- \\
25 \mathrm{~m}\end{array}$ & & 7 & & 0.7 \\
\hline 3 & & $\begin{array}{l}26 \mathrm{~m}- \\
50 \mathrm{~m}\end{array}$ & & 5 & & 0.5 \\
\hline 4 & & $\begin{array}{l}51 m- \\
75 m\end{array}$ & & 3 & & 0.3 \\
\hline 5 & & $\begin{array}{l}76 \mathrm{~m}- \\
100 \mathrm{~m}\end{array}$ & & 1 & & 0.1 \\
\hline 6 & & $>100 m$ & & 1 & & 0.1 \\
\hline 1 & Buffer & $0-25 \mathrm{~m}$ & Dekat & 7 & 20 & 1.4 \\
\hline
\end{tabular}




\begin{tabular}{|c|c|c|c|c|c|}
\hline 2 & Sungai & $\begin{array}{c}25-100 \\
m\end{array}$ & Sedang & 5 & 1 \\
\hline 3 & & $\begin{array}{c}100-250 \\
m\end{array}$ & Jauh & 3 & 0.6 \\
\hline
\end{tabular}

Sumber : Hasil Perhitungan

Peta bahaya banjir adalah overlay peta curah hujan, kemiringan lereng, peta ketinggian,peta tekstur tanah, peta penggunaan lahan dan buffer sungai. Hal ini bertujuan untuk mengetahui wilayah yang berpotensi terjadinya bahaya banjir.

Adapun hasil analisa daerah bahaya banjir adalah daerah yang dari segi fisik dan klimatologis memiliki kemungkinan terjadi banjir dalam jangka waktu tertentu dan berpotensi terhadap rusaknya alam.Bahaya banjir dalam penelitian ini terbagi menjadi empat kelas tingkat bahaya, yaitu tinggi, sedang, rendah dan aman.Pada tabel 4.11 Dibawah ini merupakan tabel bahaya banjir 23 November 2012.

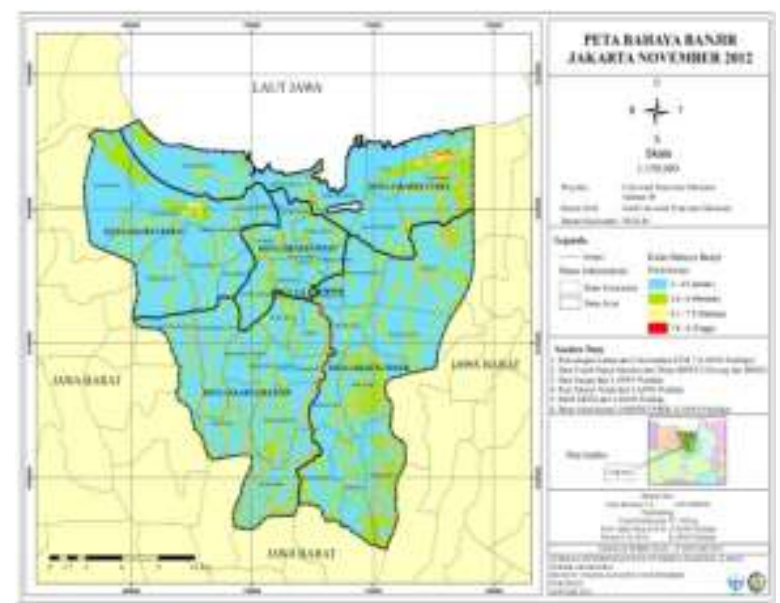

Gambar 13. Peta Bahaya Banjir 23 November 2012 Sumber: hasil penelitian

Gambar 13 dan Tabel 8 menunjukkan area mana saja yang termasuk dalam bahaya banjir.dengan luas bahaya banjir sebagai berikut.

Tabel 8. Luas Bahaya Banjir 23 Novermber 2012

\begin{tabular}{ccccc}
\hline \multicolumn{5}{c}{ Luas Bahaya Banjir 23 November 2012} \\
\hline No & Kelas & $\begin{array}{c}\text { Kelas } \\
\text { Interval }\end{array}$ & Luas (ha) & Luas (\%) \\
\hline 1 & Aman & $3-4.5$ & 64170.02 & 31.51105 \\
2 & Rendah & $4.6-6$ & 63757.14 & 31.30831 \\
3 & Sedang & $6.1-7.5$ & 63971.02 & 31.41334 \\
\hline 4 & Tinggi & $7.6-9$ & 11744.7 & 5.767303 \\
& Total & & $\mathbf{2 0 3 6 4 2 . 9}$ & $\mathbf{1 0 0}$ \\
\hline
\end{tabular}

Sumber: Hasil penelitian
Rentang kelas dari tabel 8 didapatkan dari total perhitungan bobot dengan skor masing masing parameter penyebab bahaya banjir. Dengan menggunakan rumus :

$$
K i=\frac{X t-X r}{k}
$$

Keterangan:

Ki : Kelas Interval

$\mathrm{Xt}$ : Nilai tertinggi

$\mathrm{Xr}$ : Nilai terendah

$\mathrm{k}$ : Jumlah kelas yang diinginkan

Nilai kelas interval :

Nilai tertinggi $=9$

Nilai terendah $=2$

Jumlah kelas $=4$

Tabel 9. Lokasi Bahaya Banjir menurut data 23 November 2012

\begin{tabular}{cccc}
\hline \multicolumn{4}{c}{ Lokasi Banjir Tanggal 23 November 2012 } \\
No & Kelurahan & Kecamatan & Kota \\
\hline 1 & bidara cina & Jatinegara & Jakarta Timur \\
2 & bintaro & Pesanggrahan & Jakarta Selatan \\
3 & Bukit duri & Tebet & Jakarta selatan \\
4 & caawang & Kramat Jati & Jakarta Timur \\
5 & cililitan & Kramat Jati & Jakarta Timur \\
6 & cipulir & Kebayoran Lama & Jakarta Timur \\
7 & grogol selatan & Grogol & Jakarta Barat \\
8 & Kampung & petamburan & \\
9 & melayu & Jatinegara & Jakarta Timur \\
10 & kebonwaru & Tebet & Jakarta Selatan \\
11 & pejaten timur & Pasar Minggu & Jakarta Selatan \\
12 & pondok labu & Cilandak & Jakarta Selatan \\
13 & pondok pinang & Kebayoran Lama & Jakarta selatan \\
14 & ulujami & Pesanggrahan & Jakarta Selatan \\
\hline
\end{tabular}

Sumber : BNPB 2012

Pemetaan daerah bahaya banjir ini bertujuan untuk mengidentifikasi daerah mana saja yang berpotensi untuk terjadinya banjir, sehingga daerah tersebut dapat dianalisis untuk melakukan pencegahan dan penanganan banjir.Untuk melakukan pencegahan dan penanganan banjir, faktor yang dapat dilakukan perbaikan/perubahan adalah penutupan lahan yang merupakan faktor manusia.Dimana penutupan lahan berupa pemukiman, sawah, dan tanah terbuka 
memberikan pengaruh yang besar untuk terjadinya banjir. Sedangkan faktor-faktor yang lain merupakan faktor alam yang umumnya sulit untuk dilakukan perbaikan/perubahan.

Dari hasil analisis penetapan kawasan bahaya banjir, ternyata daerah bahaya banjir yang dibuat BNPB $100 \%$ semuanya masuk dalam daerah bahaya banjir berdasarkan hasil penelitian. Hal ini terjadi karena memang setiap musim penghujan daerah-daerah bahaya tersebut selalu mengalami banjir/langganan banjir.

\section{DAFTAR PUSTAKA}

Badan Pengelolah Lingkungan Hidup Daerah (BPLHD) Provinsi DKI Jakarta.2012.Kondisi Lingkungan Hidup dan Kecenderungannya. <URL:http://bplhd.jakarta.go.id/slhd20 12/Dos/Lap SLHD/Lap 2G.htm>. Dikunjungi pada 22 Januari 2012 pada jam 05.50 AM.

Badan Koordinasi Survei dan pemetaan Nasional (BAKOSURTANAL).,2015.Peta-Provinsi. <URL:http://www.bakosurtanal.go.id/p eta-provinsi> dikunjungi tanggal 15 Januari 2015 jam 11.15 BBWI.

Kusumaputra, R.A.2010.Banjir Kanal Timur Karya Anak Bangsa. Jakarta: Grasindo.

Ramdan. 2004. Prinsip Dasar pengelolaan Daerah Aliran Sungai. Sumedang: Fakultas Kehutanan, Universitas Winaya Mukti..

Sutopo. 2012. 6 Penyebab Banjir Besar Jakarta. Dari

<URL:http://www.tempo.co/read/new s/2013/01/18/083455237/6-

Penyebab-Banjir-Besar-Jakarta $>$. Dikunjungi pada tanggal 23 April 2014. 